\title{
Assessment of some traditional cardiovascular risk factors in medical doctors in Southern Nigeria
}

This article was published in the following Dove Press journal: Vascular Health and Risk Management

\section{Tamaraemumoemi \\ Emmanuella \\ Ambakederemo' \\ Eze Uzoechi Chikezie ${ }^{2}$ \\ 'Department of Internal Medicine, Niger Delta University Teaching Hospital, Okolobiri, Bayelsa, Nigeria; 2Department of Mental Health, Niger Delta University Teaching Hospital, Okolobiri, Bayelsa, Nigeria}

Correspondence: Tamaraemumoemi Emmanuella Ambakederemo Department of Internal Medicine, Niger Delta University Teaching Hospital, P.O. Box 420, Port Harcourt, Rivers State, Nigeria

Tel +2340803309 1319

Email nuellaokoro@gmail.com
Introduction: Almost one third of deaths globally are caused by cardiovascular diseases (CVDs). Certain occupations may promote the development and worsening of risk factor for CVDs. We assessed some traditional cardiovascular risk factors and lifestyle choices that may predispose to CVDs in medical doctors in a tertiary health facility in Southern Nigeria.

Study design: Cross-sectional study

Participants and methods: One hundred sixty-nine apparently healthy medical doctors were recruited. A structured self-administered questionnaire was used to gather data on CVD risk factors. Anthropometric and blood pressure (BP) measurements were taken.

Results: Majority were males (68.0\%), aged 20-39 years (43.8\%), single (62.7\%), and house officers $(58.0 \%)$ with $<1$ year $(48.5 \%)$ work experience. Over half were either overweight or obese. While $77.2 \%$ of those not centrally obese were males, only about $22.8 \%$ of females did not meet the criteria for central obesity $(P$-value $<0.05)$. While respondents had BP in prehypertensive $(48.2 \%)$, stage 1 (18.5\%), or stage 2 hypertension (3.6\%) ranges, only $7.7 \%$ had a previous diagnosis of hypertension. Only $25.4 \%$ took fruits on a daily basis and engaged in aerobic exercises up to 30 minutes daily or at least 3-5 times a week. Other poor lifestyle choices included non-lean meat intake (76.8\%), low water intake (88.2\%), and junk food and soda drinks intake (daily $28 \%$, weekly $51.2 \%$ ).

Conclusion: Findings of a high prevalence of overweight/obesity, physical inactivity, and junk food intake and low fruits intake among doctors is worrisome. There is a need to educate doctors on adopting healthier lifestyles to reduce risk of CVDs.

Keywords: cardiovascular risk factors, medical doctors, lifestyle choices

\section{Introduction}

It is estimated that cardiovascular diseases (CVDs) accounted for 17.7 million human deaths in 2015 (which represents $31 \%$ of all global deaths), and that more than three quarters of deaths from CVDs take place in low- and middle-income countries, which would include Nigeria. ${ }^{1}$ Obesity, diabetes mellitus, dyslipidemia, smoking, and hypertension contribute individually and collectively to an increased risk of CVDs. ${ }^{2-4} \mathrm{~A}$ combination of these risk factors associated with a resultant increase in the occurrence of CVDs is a frequent finding. ${ }^{5,6}$ Certain occupations may promote the development and worsening of hypertension, obesity, and diabetes mellitus. ${ }^{7-14}$

Several studies have established a link between occupations and the development of cardiovascular risk factors and CVDs. ${ }^{7,8,15-18}$ Possible related factors include both physiologic and psychological stresses at the workplace, and worsening of cardiovascular risk profiles such as hypertension, obesity, dyslipidemia, and physical inactivity. ${ }^{15,18} \mathrm{~A}$ high 
prevalence of cardiovascular risk factors has been documented among medical students ${ }^{19-24}$ and health care workers, ${ }^{25-30}$ however, limited data are available on cardiovascular risk profiles of medical doctors. ${ }^{31,32}$ Medical doctors take the lead in the management of patients with cardiovascular risk factors and CVDs. It is important that they are healthy in order to attend to the health needs of patients. Also, a healthy-looking nonobese doctor is more likely to be comfortable with and believable by his patient when counseling on appropriate lifestyle practices and healthy diet. ${ }^{33-37}$ Doctors who counsel their patients by adding tidbits from their own personal healthy lifestyle measures may be better able at motivating patients to similar behavior, as they are perceived as being credible. ${ }^{34}$

In this study, we aimed at assessment of some traditional risk factors for CVDs in medical doctors in the Niger Delta of Nigeria.

The aims of the study were to:

1. Determine anthropometric measures, blood pressures (BPs), random blood glucose levels, personal and family history of cardiovascular risk factors/disease in the study respondents.

2. Determine the prevalence of some adverse lifestyle choices that may predispose to an increased CVD risk.

\section{Participants and methods Study population}

One hundred sixty-nine apparently healthy medical doctors were recruited consecutively from various departments in the NDUTH, Okolobiri and Federal Medical Center (FMC), Yenagoa, both in Bayelsa State. They were all above 18 years of age and included house officers, resident doctors, and consultants in various specialties and subspecialties of medicine.

\section{Study setting}

These two tertiary centers (NDUTH Okolobiri and FMC Yenagoa, Bayelsa State) serve as referral centers to several private and general hospitals in Bayelsa and Rivers states including hospitals in neighboring states such as Edo, Delta, Akwa-Ibom, and Imo in Nigeria.

\section{Study design}

A cross-sectional study.

\section{Study procedures Questionnaire}

The participants first completed a self-administered questionnaire, which was developed by the authors in line with the
WHO STEPwise approach to Surveillance guidelines used in similar studies. ${ }^{5,13,38}$ This was used to gather data regarding their sociodemographic details, which included age, sex, marital status, current level of work experience, that is, housemanship, residency training, or consultants' position including specialty/subspecialty and duration of practice. Other data included a history of being a known hypertensive and/or diabetic patient and medications being taken for either or both conditions. Also elicited was history of cigarette smoking, amount of alcohol intake weekly, amount of daily/ weekly aerobic exercise, salt intake, daily fruit intake, usual animal protein source, frequency of junk food intake, and family history of hypertension and diabetes.

\section{Physical measurements}

These were done by house officers (intern doctors) who had received training on how to take required measurements. All data collectors were trained to adhere to strict procedural guidelines in the measurement of all the parameters considered in this study. The several measurements done had procedural guidelines that were effectively communicated during the training of data collectors and adhered to while collecting data.

Height was measured in meters using a standardized heighto-meter (PGZ-160 Pyrochy medical, Onitsha, Anambra State, Nigeria) with the subject standing feet together with no shoes on, against a vertical ruled bar to which a movable horizontal bar was attached. During the measurement, the horizontal bar was brought to the vertex of the subject's head, and the reading at this level was taken to the nearest millimeter. They were also made to stand upright on the scale, not leaning on any support/ wall with their heads up before the readings were taken.

Weight was measured in kilograms with the subject wearing only light clothing. It was ensured that participants removed their shoes, brought out everything in the pocket like phones and keys, dropped handbags, and were relieved of any material that could have increased weight temporarily. Additionally, it was ensured that the scale was on the zero mark before each participant climbed on it for the measurement. A standardized weight scale was used (PGZ-160 Pyrochy medical). Each subject's body mass index (BMI) was calculated as weight in $\mathrm{kg}$ divided by the square of the height in meters $\left(\mathrm{kg} / \mathrm{m}^{2}\right)$. Obesity was defined as a BMI of $\geq 30 \mathrm{~kg} / \mathrm{m}^{2}$ using the WHO categorization. ${ }^{38}$ Also, BMI of $<18.5,18.5-24.9$, and $25-29.9 \mathrm{~kg} / \mathrm{m}^{2}$ were characterized as underweight, normal, and overweight, respectively. ${ }^{39}$ Waist circumference (WC) was measured (to the nearest $0.1 \mathrm{~cm}$ ) at the approximate midpoint between the lower margin of the last palpable rib and the top of the iliac 
crest ${ }^{40} \mathrm{using}$ a nonstretch linear tape. Hip circumference (HC) was measured (in centimeters) at the widest diameter of the hips over the greater trochanters. Waist-to-hip ratio (WHR) was calculated as WC divided by $\mathrm{HC} .{ }^{40} \mathrm{WC}$ cutoff of $94 \mathrm{~cm}$ for European men and $80 \mathrm{~cm}$ for European women were regarded as elevated and indicative of abdominal obesity. ${ }^{41-44}$ Abdominal obesity was also defined as a WHR $>0.90$ in males and $>0.85$ in females. ${ }^{40} \mathrm{~A}$ waist-to-height ratio (WHtR) of $\geq 0.5$ was also indicative of central obesity. ${ }^{45}$

The BPs were measured at presentation by house officers (intern doctors) and resident doctors who had been trained to take required measurements. An Accoson mercury sphygmomanometer was used to determine the brachial artery systolic and diastolic BPs at Korotkoff 1 and 5, respectively, in sitting position after 30 minutes rest, with the arm at heart level and readings taken at the nearest $2 \mathrm{mmHg}$. Two BP recordings were taken from the right arm of patients with measurements being taken at 5-minute intervals. The average of two measurements was then used for the analysis. ${ }^{46} \mathrm{BP}$ readings were based on the Seventh Report of the Joint National Committee on Prevention, Detection, Evaluation, and Treatment of High Blood Pressure (JNC VII) classification and guidelines. ${ }^{47}$ Random blood glucose level was determined before participant's lunch. Diabetes mellitus and impaired glucose tolerance were defined by a random blood glucose of $>11.1$ and $>7.8 \mathrm{mmol} / \mathrm{L}$, respectively. The measurements were taken by either the principal investigator or well-trained house officers.

\section{Data analysis}

The responses obtained from the respondents were entered into excel sheet and analyzed using SPSS version 20 software. The data analysis consisted of descriptive statistics, based on the various objectives of the study.

The sociodemographic features of the respondents were analyzed descriptively and presented in tables as frequencies and their percentages, but the age of the respondents was further presented in mean and SD, being a continuous variable. All other continuous variables like BMI, WHR, WHtR, $\mathrm{WC}$, systolic and diastolic BPs, pulse rate, and random blood sugar were presented in tables as mean and SD, including their minimum and maximum values.

To identify the presence of adverse risk factors that predispose to CVDs, all the listed lifestyles were descriptively presented, to show their distribution in the sample population.

The height and weight of respondents were used to obtain BMI, which was further classified into normal and overweight/obese categories; with systolic and diastolic BPs, classification of possible hypertensive status of respondents was obtained. Applying inferential statistics, Pearson's chisquared test and independent $t$-test were used to test for association between outcome variables of the study and gender. Associations with a $P$-value $\leq 0.05$ were considered statistically significant. Furthermore, ANOVA test was applied in determining the association between anthropometric parameters and age groups among respondents.

\section{Ethics statement}

Approval and consent were obtained from the research and ethics committee of NDUTH Okolobiri, and only respondents who gave informed consent were recruited for the study. Pregnant females were excluded from the study.

\section{Results}

There were $68 \%$ males and $32 \%$ females in this study as shown in Table 1; most of the respondents are in the 20-39 age group in years $(85.2 \%)$; single $(62.7 \%)$ and mostly house officers $(58 \%)$.

Table 2 shows the mean and SDs of anthropometric variables of the respondents and also shows the minimum and maximum values.

Table I Sociodemographic profile of respondents

\begin{tabular}{|l|l|l|}
\hline Variables & Count $(\mathbf{n}=\mathbf{1 6 9})$ & $\begin{array}{l}\mathbf{N} \\
\mathbf{( \% )}\end{array}$ \\
\hline Gender & 115 & \\
Male & 54 & 68.0 \\
Female & & 32.0 \\
\hline Age (in years) & 74 & \\
$20-29$ & 70 & 43.8 \\
$30-39$ & 13 & 41.4 \\
$40-49$ & 12 & 7.7 \\
$\geq 50$ & & 7.1 \\
\hline Marital status & 106 & \\
Single & 63 & 62.7 \\
Married & & 37.3 \\
\hline Cadre of staff & 98 & \\
House officer & 51 & 58.0 \\
Resident & 20 & 30.2 \\
Consultant/Professor & & 11.8 \\
\hline Number of years in practice & 82 & \\
$<1$ & 54 & 48.5 \\
I-5 & 12 & 32.0 \\
$6-10$ & 9 & 7.1 \\
II-20 & 8 & 5.3 \\
$21-30$ & 4 & 4.7 \\
$>30$ & & 2.4 \\
Mean $=4.53 \pm 8.20$ years & & \\
\hline
\end{tabular}


As shown in Table 3, over half of the respondents were either overweight or obese.

In associating outcome variables of the study with sex of respondents, Table 4 shows that $77.2 \%$ of those who were not centrally obese were males and only about $22.8 \%$ of the respondents in this category were females $(P$-value $<0.05)$.

Table 5 shows ANOVA test among categories of age group and the mean scores of the various anthropometric measurements. It shows a statistically significant association between

Table 2 Age, blood pressure, and anthropometric features of respondents

\begin{tabular}{|c|c|c|c|}
\hline Variables & Mean \pm SD & $\begin{array}{l}\text { Range } \\
\text { Minimum }\end{array}$ & Maximum \\
\hline Age (years) $n=169$ & $32.49 \pm 8.73$ & 23 & 67 \\
\hline $\begin{array}{l}\text { Body mass index } \\
\left(\mathrm{kg} / \mathrm{m}^{2}\right) \mathrm{n}=169\end{array}$ & $25.58 \pm 3.75$ & 19 & 38 \\
\hline $\begin{array}{l}\text { Waist circumference } \\
(\mathrm{cm}) \mathrm{n}=169\end{array}$ & $86.60 \pm 10.65$ & 68 & 116 \\
\hline $\begin{array}{l}\text { Waist-height ratio } \\
n=168\end{array}$ & $0.5 \mathrm{I} \pm 0.06$ & 0.40 & 0.68 \\
\hline $\begin{array}{l}\text { Waist-hip ratio } \\
n=168\end{array}$ & $0.90 \pm 0.08$ & 0.67 & 1.27 \\
\hline $\begin{array}{l}\text { Systolic blood } \\
\text { pressure }(\mathrm{mmHg}) \\
\mathrm{n}=168\end{array}$ & $119.55 \pm 11.77$ & 80 & 150 \\
\hline $\begin{array}{l}\text { Diastolic blood } \\
\text { pressure }(\mathrm{mmHg}) \\
\mathrm{n}=168\end{array}$ & $77.24 \pm 9.84$ & 60 & 100 \\
\hline $\begin{array}{l}\text { Resting pulse rate } \\
\text { (bpm) } n=169\end{array}$ & $75.4 I \pm 9.23$ & 60 & 112 \\
\hline $\begin{array}{l}\text { Random blood sugar } \\
(\mathrm{mmol} / \mathrm{L}) \mathrm{n}=169\end{array}$ & $5.00 \pm 1.17$ & 3 & 12 \\
\hline
\end{tabular}

Table 3 Outcome variables of the study

\begin{tabular}{|l|l|l|}
\hline Characteristics & Count & N (\%) \\
\hline BMI & 80 & \\
Normal (BMI $\left.=18.5-24.9 \mathrm{~kg} / \mathrm{m}^{2}\right)$ & 66 & 47.3 \\
Overweight $\left(\mathrm{BMI}=25-29.9 \mathrm{~kg} / \mathrm{m}^{2}\right)$ & 23 & 39.1 \\
Obese $\left(\mathrm{BMI} \geq 30 \mathrm{~kg} / \mathrm{m}^{2}\right)$ & & 13.6 \\
Waist circumference & 106 & \\
$\begin{array}{l}\text { Normal }(<94 \mathrm{~cm} \text { for men, }<80 \mathrm{~cm} \\
\text { for women) }\end{array}$ & 62.7 \\
$\begin{array}{l}\text { Overweight/Obese }(>94 \mathrm{~cm} \text { for } \\
\text { men, }>80 \mathrm{~cm} \text { for women) }\end{array}$ & \\
$\begin{array}{l}\text { Waist-hip ratio } \\
\text { Low risk }(<0.9 \text { for men, }<0.85 \text { for }\end{array}$ & 79.3 \\
women) & & \\
High risk $(>0.9$ for men, $>0.85$ for & 89 & 47.0 \\
women) & & 53.0 \\
Waist-height ratio & 79 & \\
Low risk $(<0.5)$ & 89 & 47.0 \\
High risk $(\geq 0.5)$ & 53.0 \\
\hline
\end{tabular}

Abbreviation: BMI, body mass index. the age groups and BMI, WC, systolic blood pressure (SBP), diastolic blood pressure (DBP), and pulse rate; $P$-values are $<0.05$ at $95 \% \mathrm{CI}$.

As shown in Table 6, only $7.7 \%$ of respondents had been previously diagnosed with hypertension, $63.6 \%$ of which were on thiazide diuretic combination antihypertensives. The table also shows that $56.2 \%$ of the respondents have a positive history of hypertension in a first-degree relative while only $27.4 \%$ had a positive family history of diabetes mellitus. The table further reveals that majority of the respondents had BPs in prehypertensive (48.2\%), stage 1 hypertension (18.5\%), or stage 2 hypertension $(3.6 \%)$ ranges. ${ }^{47}$ None of the respondents suffered from diabetes mellitus, hence there were no data to analyze the variable.

As shown in Table 7, 94.7\% respondents are nonsmokers, and up to one third of the respondents took alcohol in a range of 1-50 units weekly with a mean of $7.25 \pm 8.59$ units weekly. Only $25.4 \%$ engage in aerobic exercises up to 30 minutes daily or at least 3-5 times a week. Only $25.4 \%$ took fruits on a daily basis, and $76.8 \%$ had beef as source of animal protein. Water intake was low for most of the respondents $(88.2 \%)$. Twenty-eight percent of the respondents took junk foods (eg, deep-fried snacks, pizzas, burgers, chips, meat pies) and soda drinks on a daily basis, while $51.2 \%$ did so on a weekly basis. Only $8.9 \%$ had the habit of adding extra salt to already prepared meals.

\section{Discussion}

Over half of the respondents were either overweight or obese. Obesity affects a large proportion of the world's population with the inclusion of health professionals. ${ }^{48-52}$ Prevalence of overweight/obesity in medical doctors has previously been reported to be up to $48 \%-65 \% .{ }^{52-54}$

When anthropometric measures were associated with the sexes of respondents, three quarters of those who were not centrally obese were males. We made this assessment using WC and WHR, both of which have been shown to be strongly associated with central fat localization, ${ }^{55-57}$ and are sensitive measures of central obesity. Central obesity is thought to be more pathogenic than overall obesity and also contributes more to CVDs than overall obesity. ${ }^{58-60}$ Several studies show that women are more likely to be centrally obese than men. ${ }^{55,56,61-63}$

The current study also showed a statistically significant association between the age groups and BMI, WC, SBP, and DBP. Advancing age is a risk factor for obesity and hypertension. ${ }^{64,65}$ There was also a significant association between the age groups and resting pulse rate. Elevated 
Table 4 Outcome variables of the study compared in males vs females

\begin{tabular}{|c|c|c|c|c|}
\hline \multirow[t]{2}{*}{ Characteristics } & \multicolumn{2}{|c|}{ Sex of respondents } & \multirow{2}{*}{$\begin{array}{l}\text { Chi-squared test } \\
\chi^{2}\end{array}$} & \multirow[t]{2}{*}{$P$-value } \\
\hline & $\begin{array}{l}\text { Males } \\
\mathrm{N}(\%)\end{array}$ & $\begin{array}{l}\text { Females } \\
\mathbf{N}(\%)\end{array}$ & & \\
\hline $\begin{array}{l}\text { BMI } \\
\text { Normal }\left(B M I=I 8.5-24.9 \mathrm{~kg} / \mathrm{m}^{2}\right) \\
\text { Overweight }\left(B M I=25-29.9 \mathrm{~kg} / \mathrm{m}^{2}\right) \\
\text { or obese }\left(B M I \geq 30 \mathrm{~kg} / \mathrm{m}^{2}\right)\end{array}$ & $\begin{array}{l}50(62.5) \\
65(73.0)\end{array}$ & $\begin{array}{l}30(37.5) \\
24(27.0)\end{array}$ & 2.15 & 0.14 \\
\hline $\begin{array}{l}\text { Waist circumference } \\
\text { Normal (<94 cm for men, }<80 \mathrm{~cm} \text { for } \\
\text { women) } \\
\text { Overweight/Obese ( }>94 \mathrm{~cm} \text { for men, } \\
>80 \mathrm{~cm} \text { for women) }\end{array}$ & $\begin{array}{l}61(77.2) \\
54(59.6)\end{array}$ & $\begin{array}{l}18(22.8) \\
36(40.4)\end{array}$ & 5.99 & 0.01 \\
\hline $\begin{array}{l}\text { Waist-hip ratio } \\
\text { Low risk ( }<0.9 \text { for men, }<0.85 \text { for } \\
\text { women) } \\
\text { High risk ( }>0.9 \text { for men, }>0.85 \text { for } \\
\text { women) }\end{array}$ & $\begin{array}{l}61(77.2) \\
53(20.0)\end{array}$ & $\begin{array}{l}18(22.8) \\
36(80.0)\end{array}$ & 38.18 & 0.00 \\
\hline $\begin{array}{l}\text { Waist-height ratio } \\
\text { Low risk }(<0.5) \\
\text { High risk }(\geq 0.5)\end{array}$ & $\begin{array}{l}51 \text { (64.6) } \\
63(70.8)\end{array}$ & $\begin{array}{l}28(35.4) \\
26(29.2)\end{array}$ & 0.75 & 0.39 \\
\hline
\end{tabular}

Abbreviation: BMI, body mass index.

Table 5 Comparison of study variables among age groups

\begin{tabular}{|c|c|c|c|c|c|c|}
\hline \multirow[t]{2}{*}{ Parameters } & \multicolumn{4}{|c|}{ Age group (years) } & \multicolumn{2}{|c|}{ ANOVA test } \\
\hline & $20-29$ & 30-39 & $40-49$ & $\geq 50$ & $\mathbf{F}$ & $P$-value \\
\hline BMI & $24.62 \pm 3.16$ & $25.66 \pm 3.73$ & $26.23 \pm 3.44$ & $30.33 \pm 4.12$ & 9.41 & 0.00 \\
\hline WC & $84.09 \pm 8.78$ & $85.05 \pm 9.16$ & $92.15 \pm 10.45$ & $105.08 \pm 10.49$ & 20.25 & 0.00 \\
\hline $\mathrm{WHtR}$ & $0.5 \mathrm{I} \pm 0.07$ & $0.5 I \pm 0.06$ & $0.48 \pm 0.04$ & $0.50 \pm 0.04$ & 1.03 & 0.38 \\
\hline WHR & $0.89 \pm 0.08$ & $0.91 \pm 0.08$ & $0.87 \pm 0.07$ & $0.88 \pm 0.07$ & 1.34 & 0.26 \\
\hline SBP & $118.52 \pm 11.10$ & $117.5 \mathrm{I} \pm 11.35$ & $124.62 \pm 11.98$ & $132.17 \pm 9.82$ & 6.95 & 0.00 \\
\hline DBP & $76.53 \pm 9.24$ & $75.7 I \pm 9.72$ & $81.08 \pm 6.46$ & $86.33 \pm 12.12$ & 5.11 & 0.00 \\
\hline PR & $73.09 \pm 7.26$ & $76.79 \pm 9.48$ & $75.38 \pm 12.20$ & $81.67 \pm 11.59$ & 4.13 & 0.01 \\
\hline RBS & $4.89 \pm 1.12$ & $5.21 \pm 1.26$ & $4.69 \pm 0.63$ & $4.75 \pm 1.29$ & 1.49 & 0.22 \\
\hline
\end{tabular}

Notes: Results reported as mean \pm SD; significant at $P<0.05$.

Abbreviations: BMI, body mass index; DBP, diastolic blood pressure; PR, pulse rate; RBS, random blood sugar; SBP, systolic blood pressure; WC, waist circumference; WHtR, waist-to-height ratio; WHpR, waist-to-hip ratio.

resting pulse rate (RPR) is strongly associated with adverse cardiovascular outcomes. ${ }^{66,67}$ Mean RPR in our respondents was $81.67 \pm 11.59 \mathrm{bpm}$. Elevated RPR $>80 \mathrm{bpm}$ often leads to rupture of atherosclerotic plaques and consequent occurrence of acute coronary syndrome. ${ }^{68,69}$

Only $7.7 \%$ of the respondents had been previously diagnosed with hypertension; however, $22.1 \%$ had BP $\geq 140$ $\mathrm{mmHg}$ SBP and/or DBP $\geq 90 \mathrm{mmHg}$. Majority (48.2\%) had $\mathrm{SBP}$ in the range of $120-139$ and/or DBP $80-89 \mathrm{mmHg}$; however, BP reading was done only once. Detection of hypertension remains low in sub-Saharan Africa because of poor awareness and a highly deficient and underfunded health system. ${ }^{61-63,70,71}$ Medical doctors show low rates of undergoing routine medical checks on themselves ${ }^{72}$ despite possibly dying more from physical illnesses than mental health challenges, which have been the foci of most studies on doctors' health and health-related behaviors. ${ }^{73}$ Doctors may have a high prevalence of chronic illnesses ${ }^{74}$ with prevalence rate of CVDs of $4 \%-15 \%$ previously reported. ${ }^{75-77}$

Out of all the study respondents who had been previously diagnosed hypertensive and were on antihypertensive medications, $63.6 \%$ of them were on antihypertensive combinations that included thiazide diuretics. Over two thirds of hyperten- 
Table 6 History of hypertension, diabetes mellitus, and body mass index of respondents

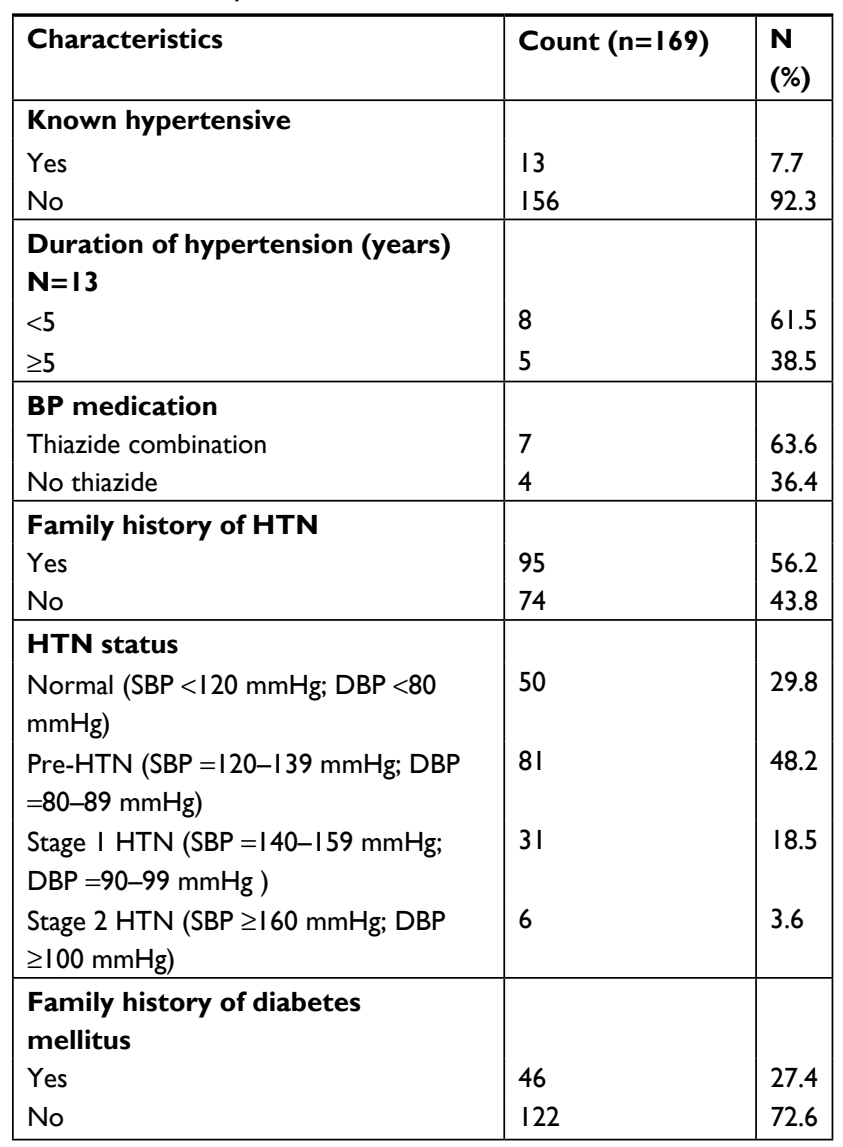

Abbreviations: BP, blood pressure; DBP, diastolic blood pressure; HTN, hypertension; SBP, systolic blood pressure.

sive patients cannot achieve BP control on one drug alone and require two or more antihypertensive drugs from different classes. ${ }^{78-80}$ Thiazide diuretics are first-line antihypertensive agents ${ }^{47}$ and are the most frequently prescribed antihypertensives in Nigeria and sub-Saharan Africa at large usually in combination with dihydropyridine calcium-channel blockers, angiotensin-converting enzyme inhibitors, or angiotensin receptor blockers. ${ }^{81-83}$

A positive history of hypertension in a first-degree relative was present in over half of the respondents. A positive family history of hypertension is a risk factor for hypertension, obesity, dyslipidemia, type 2 diabetes mellitus, and CVDs ${ }^{84-86}$ and several studies have shown an increased prevalence of hypertension among first-degree relatives of hypertensive patients. ${ }^{86,87}$

Only $27.4 \%$ of the respondents had a positive family history of diabetes mellitus. Previous studies have shown a prevalence rate of $10.3 \%-26.9 \%$ in first-degree relatives of type 1 and/or type 2 diabetic patients. ${ }^{88,89}$ Having a first-degree
Table 7 Some lifestyle characteristics of respondents

\begin{tabular}{|c|c|c|}
\hline Characteristics & $\begin{array}{l}\begin{array}{l}\text { Count } \\
(n=169)\end{array} \\
\end{array}$ & $\begin{array}{l}\mathbf{N} \\
\%\end{array}$ \\
\hline $\begin{array}{l}\text { Smoking status } \\
\text { Smoker (mean pack years } \\
2.50 \pm I .73 \text {, range I-5 pack years) } \\
\text { Nonsmoker }\end{array}$ & $\begin{array}{l}9 \\
160\end{array}$ & $\begin{array}{l}5.3 \\
94.7\end{array}$ \\
\hline $\begin{array}{l}\text { Alcohol consumption status } \\
\text { Takes alcohol (mean } 7.25 \pm 8.59 \\
\text { units weekly, range I-50 units } \\
\text { weekly) } \\
\text { No alcohol intake }\end{array}$ & $\begin{array}{l}61 \\
108\end{array}$ & 63.9 \\
\hline $\begin{array}{l}\text { Exercise } \\
\text { Aerobic exercise } 30 \text { minutes daily } \\
\text { or } 3-5 \text { times a week } \\
\text { No aerobic exercise }\end{array}$ & $\begin{array}{l}43 \\
126\end{array}$ & $\begin{array}{l}25.4 \\
74.6\end{array}$ \\
\hline $\begin{array}{l}\text { Consumes fruits daily } \\
\text { Yes } \\
\text { No }\end{array}$ & $\begin{array}{l}43 \\
126 \\
\end{array}$ & $\begin{array}{l}25.4 \\
74.6 \\
\end{array}$ \\
\hline $\begin{array}{l}\text { Adds extra salt to meals } \\
\text { Yes } \\
\text { No }\end{array}$ & $\begin{array}{l}15 \\
154 \\
\end{array}$ & $\begin{array}{l}8.9 \\
91.1\end{array}$ \\
\hline $\begin{array}{l}\text { Main source of protein } \\
\text { Beef only } \\
\text { Beef and chicken } \\
\text { Beef, chicken, and fish } \\
\text { Beef and fish } \\
\text { Chicken and fish } \\
\text { Fish only } \\
\text { Beef, chicken, fish, and pork }\end{array}$ & $\begin{array}{l}33 \\
9 \\
50 \\
23 \\
20 \\
19 \\
14\end{array}$ & $\begin{array}{l}19.6 \\
5.4 \\
29.8 \\
13.7 \\
11.9 \\
11.3 \\
8.3\end{array}$ \\
\hline $\begin{array}{l}\text { Daily water intake } \\
\text { Low ( }<2.7 \mathrm{~L} \text { for women, }<3.7 \mathrm{~L}\end{array}$ & 149 & 88.2 \\
\hline $\begin{array}{l}\text { for men) } \\
\text { Moderate ( } 2.7 \mathrm{~L} \text { for women, } 3.7 \\
\text { L for men) }\end{array}$ & 12 & 7.1 \\
\hline $\begin{array}{l}\text { High ( }>2.7 \mathrm{~L} \text { for women, }>3.7 \mathrm{~L} \\
\text { for men) }\end{array}$ & 8 & 4.7 \\
\hline Junk food/soda drinks & & \\
\hline $\begin{array}{l}\text { Take daily } \\
\text { Take weekly } \\
\text { Take monthly } \\
\text { Do not take }\end{array}$ & $\begin{array}{l}47 \\
86 \\
4 \\
31\end{array}$ & $\begin{array}{l}28.0 \\
51.2 \\
2.4 \\
18.5\end{array}$ \\
\hline
\end{tabular}

relative with type 2 diabetes mellitus may increase the risk of becoming diabetic by as much as $40 \%{ }^{89}$

Few of the respondents smoked cigarettes $(5.3 \%$, all males). The World Bank collection of development indicators reported a prevalence of $17.4 \%$ of smoking among Nigerian male adults in $2015 .{ }^{90}$ The WHO report on global tobacco epidemic, $2017^{91}$ also reported a prevalence of adult tobacco/cigarette smoking of $10 \% / 7.2 \%$ in adults; however, we had a lower prevalence of smoking among doctors in this study. 
Up to one third of respondents took alcohol in a range of 1-50 units weekly with a mean of $7.25 \pm 8.59$ units weekly. Alcohol intake $>14$ units weekly for women and $>21$ units per week for men is associated with increased risk of CVDs; ${ }^{92-94}$ it is, therefore, worrisome that we had a medical doctor taking up to 50 units of alcohol weekly.

In the current study, majority of the respondents (74.6\%) did not perform aerobic exercises up to 30 minutes daily or at least 3-5 times a week. Low rates of physical activity are associated with obesity, hypertension, type 2 diabetes mellitus, dyslipidemias, and cardiovascular events such as stroke. ${ }^{95-99}$ Low levels of aerobic activity have been reported among physicians. ${ }^{100}$ This has been blamed on the rigors of medical training and the residency programs that are very stressful and leave medical students and residency trainees little time and incentive to eat healthy and be physically active. ${ }^{101}$ Such bad habits may be carried over after medical training. ${ }^{100,101,102}$

Over two thirds of the study respondents admitted that they did not take fruits on a daily basis. Low fruit intake is associated with increased risk of hypertension and CVDs. ${ }^{103-106}$ Fruits and vegetables contain potassium and high potassium intake is associated with $\mathrm{BP}$ reduction in both normotensive and hypertensive individuals. ${ }^{107-109}$ Dietary approach to stop hypertension (DASH) diet recommends 4-5 servings of fruits daily. ${ }^{109}$

Majority (76.8\%) of the respondents preferred to eat beef (non-lean red meat) as a source of animal protein. Intake of beef may be associated with increased risk of hypertension and coronary heart disease because of the high saturated fat content of beef. ${ }^{110-112}$ Reduced consumption of meats, especially red meats or non-lean meats, and greater consumption of fruits and vegetables are recommended by the American Heart Association based on the findings from several studies. ${ }^{113}$ All animal products contain cholesterol and may be best avoided even though many doctors still recommend inclusion of chicken and fish in meals. ${ }^{114}$ Choline, which is a nutrient that is found in meat and fish, may increase a person's risk for heart disease, through the production of its pro-atherosclerotic metabolite, trimethylamine-N-oxide (TMAO). ${ }^{115}$ An elevated TMAO level has been associated with increased platelet activation, blood clotting, and an increased risk of major adverse cardiovascular events even after adjustment for traditional cardiovascular risk factors. ${ }^{116}$ The study found that those with the highest levels of TMAO were 2.5 times more likely to suffer from an adverse cardiovascular event, compared to those who had the lowest levels. ${ }^{15,116}$
Almost $90 \%$ of respondents took $<2.7 \mathrm{~L}$ of plain water for women and $<3.7 \mathrm{~L}$ of plain water on a daily basis for men. For an average, healthy adult living in a temperate climate, the recommended daily fluid intake deemed as adequate is about 15.5 cups $(3.7 \mathrm{~L})$ of fluids for men and about 11.5 cups $(2.7 \mathrm{~L})$ of fluids a day for women and includes fluids from water, other beverages, and food. ${ }^{117}$ However, persons in hot tropical climates such as ours typically need more water to stay adequately hydrated. Several studies suggest that low intake of plain water is associated with other less desirable behaviors such as poor dietary quality and lifestyle ${ }^{118,119}$ and may be associated with obesity, ${ }^{120-123}$ and type 2 diabetes ${ }^{124}$ if substituted with sugar-sweetened beverages.

Daily intake of junk foods and soda drinks as found among $28 \%$ of study participants in this study is associated with increased risk of obesity, hypertension, and CVDs such as stroke, heart failure, and ischemic heart disease. ${ }^{125-130}$

Adding salt to prepared food was low in occurrence among study participants. DASH diet and other healthy living food guidelines have shown that added salt to prepared meals increases CVD risk. ${ }^{131-134}$

\section{Study limitations}

BP measurement was done only once; hence, respondents with $b p \geq 140 / 90 \mathrm{mmHg}$ could not be defined as being hypertensive. Weight and height were also measured only once. The respondents were apparently healthy medical doctors who did not report any symptoms or signs of ill health; however, no blood work was done to prove that they were within all normal healthy parameters.

\section{Conclusions}

Our findings of a high prevalence of several cardiovascular risk factors including overweight/obesity, physical inactivity, junk food intake, and low fruits intake among doctors who advise patients against similar lifestyles is worrisome. These factors are known to be associated with an overall negative impact on cardiovascular health. Routine screening of medical doctors for cardiovascular risk factors is needed. Also, interventions to help doctors adopt healthier lifestyles are needed. In America, their National Academy of Sciences recommends a minimum of 25 hours of instruction be set aside for nutritional education but many of their medical schools fall far short of this recommendation. ${ }^{135}$ We need to institute such bars for learning of nutritional quality and behavioral changes here in our Nigerian medical schools and aspire to achieve them so 
we can possibly raise a generation of healthy-eating medical doctors with good cardiovascular health.

\section{Data sharing statement}

The datasets analyzed during the current study are available from the corresponding author on reasonable request.

\section{Acknowledgments}

The author is grateful to all the medical doctors who consented to be part of the study and also to the management of both the Niger Delta University Teaching Hospital, Okolobiri and Federal Medical Center Yenagoa, Bayelsa State.

\section{Authors contributions}

TEA designed the study, wrote the protocol, and managed both the statistical analysis and literature research, while TEA and EUC both contributed to writing the final manuscript. All authors contributed toward data analysis, drafting and revising the paper and agree to be accountable for all aspects of the work.

\section{Disclosure}

The authors report no conflicts of interest in this work.

\section{References}

1. World Health Organization Cardiovascular diseases (CVDs) fact sheet. Updated May 2017. http:/www.who.int/news-room/fact-sheets/detail/ cardiovascular-diseases-(cvds). Accessed April 2, 2018.

2. Tibazarwa K, Ntyintyane L, Sliwa K, et al. A time bomb of cardiovascular risk factors in South Africa: results from the Heart of Soweto Study “Heart Awareness Days". Int J Cardiol. 2009;132;(2):233-239.

3. Hill JO, Peters JC, Catenacci VA, Wyatt HR. International strategies to address obesity. Obes Rev. 2008;9(s1):41-47.

4. Dalal S, Beunza JJ, Volmink J, et al. Non-communicable diseases in sub-Saharan Africa: what we know now. Int J Epidemiol. 2011;40(4):885-901.

5. Iloh GUP, Chuku A, Obiegbu NP, Ofoedu JN, Ikwudinma AO. Frequency of cardiovascular risk factors in adult Nigerians with family history of non-communicable cardiovascular disease in a primary care clinic of a tertiary hospital in a resource-constrained environment of Eastern Nigeria. Am J Health Res. 2013;1(1):17-25.

6. Ambakederemo TE, Dodiyi-Manuel ST. Associations of anthropometric variables of obesity with blood pressure and gender disparities observed in a referral hospital in the Niger Delta of Nigeria. Saudi J Med Pharm Sci. 2017;3(4):239-244.

7. Zibaeenezhad MJ, Shahbazi H, Moaref AR, et al. Systolic and diastolic blood pressure among three groups of occupation. Iran Cardiovasc Res J. 2011;5(3):87-91.

8. Belkić K, Emdad R, Theorell T. Occupational profile and cardiac risk: possible mechanisms and implications for professional drivers. Int $J$ Occup Med Environ Health. 1998;11:37-57.

9. Niedhammer I, Goldberg M, Leclerc A, David S, Bugel I, Landre MF. Psychosocial work environment and cardiovascular risk factors in an occupational cohort in France. J Epidemiol Commun Health. 1998;52(2):93-100.

10. Mariammal T, Jaisheeba AA, Sornaraj R. Work influenced occupational stress and cardiovascular risk among teachers and office workers. $J$ Chem Pharm Res. 2012;4(3):1807-1811.
11. Salaudeen AG, Musa OI, Babatunde OA, Atoyebi OA, Durowade KA, Omokanye LO. Knowledge and prevalence of risk factors for arterial hypertension and blood pressure pattern among bankers and traffic wardens in Ilorin, Nigeria. Afr Health Sci. 2014;14(3):593.

12. Souza BB, Monteze NM, de Oliveira PFL, et al. Lifetime shift work exposure: association with anthropometry, body composition, blood pressure, glucose and heart rate variability. Occup Environ Med. 2015;72(3):208-215.

13. Chakma JK, Gupta S. Lifestyle practice and associated risk factors of noncommunicable diseases among the students of Delhi University. Int J Health Allied Sci. 2017;6:20-25.

14. Adedoyin RA, Awotidebe TO, Borode AO, et al. Comparison of blood pressure patterns of teaching and non-teaching staff of a Nigerian University. Int J Clin Med. 2016;7(7):454-460.

15. Bugajska J, Jędryka-Góral A, Widerszal-Bazyl M, et al. Job strain, overtime, life style, and cardiovascular risk in managers and physical workers. Int J Occup Saf Ergon. 2011;17(1):25-32.

16. Ramey SL, Downing NR, Franke WD, Perkhounkova Y, Alasagheirin $\mathrm{MH}$. Relationships among stress measures, risk factors, and inflammatory biomarkers in law enforcement officers. Biol Res Nurs. 2012;14(1):16-26.

17. Schumann B, Seidler A, Kluttig A, Werdan K, Haerting J, Greiser KH. Association of occupation with prevalent hypertension in an elderly East German population: an exploratory cross-sectional analysis. Int Arch Occup Environ Health. 2011;84(4):361-369.

18. Fujishiro K, Diez Roux AV, Landsbergis P, et al. Associations of occupation, job control and job demands with intima-media thickness: the Multi-Ethnic Study of Atherosclerosis (MESA). Occup Environ Med. 2011;68(5):319-326.

19. Nyombi KV, Kizito S, Mukunya D, et al. High prevalence of hypertension and cardiovascular disease risk factors among medical students at Makerere University College of Health Sciences, Kampala, Uganda. BMC Res Notes. 2016;9(1):110.

20. Giri S, Sharma SR, Timalsina S, et al. Cardiovascular health risk behavior among medical students in a teaching hospital. J Nepal Health Res Counc. 2012;10(22):187-191.

21. Rahlenbeck SI, Gebre-Yohannes A. Cardiovascular risk factors in Ethiopian medical students. Ann Biol Clin. 1998;56(6):705-709.

22. Adams-Campbell LL, Nwankwo MU, Omene JA, et al. Assessment of cardiovascular risk factors in Nigerian students. Arterioscler Thromb Vasc Biol. 1988;8(6):793-796.

23. Aslam F, Mahmud H, Waheed A. Cardiovascular healthbehaviour of medical students in Karachi. J Pak Med Assoc. 2004;54(9):492-495.

24. Bertsias G, Mammas I, Linardakis M, Kafatos A. Overweight and obesity in relation to cardiovascular disease risk factors among medical students in Crete, Greece. BMC Public Health. 2003;3(1):8.

25. Copertaro A, Bracci M, Barbaresi M, Santarelli L. Assessment of cardiovascular risk in shift healthcare workers. Eur J Cardiovasc Prev Rehabil. 2008;15(2):224-229.

26. Hazmi H, Ishak WR, Jalil RA, et al. Traditional cardiovascular riskfactors among healthcare workers in Kelantan, Malaysia. Southeast Asian J Trop Med Public Health. 2015;46(3):504-511.

27. Krusun N, Sawanyawisuth K, Chaiear N. Health status of health care workers at Srinagarind Hospital: experience from the Annual Health Check-up Program. J Med Assoc Thai. 2005;88:1619-1623.

28. Mion Jr. D, Pierin AMG, Bambirra AP, et al. Hypertension in employees of a university general hospital. Rev Hosp Clín. 2004;59(6):329-336.

29. Department of Health. Statistical Annual Report of Medical Care, National Health Insurance 2004. Taipei, Taiwan: Department of Health, Executive Yuan; 2004.

30. Boreham CAG, Gamble RP, Wallace WFM, Cran GW, Stevens AB. The health status of an ambulance service. Occup Med. 1994;44(3):137-140.

31. Hartwig B, Nichols A. GP Health \& Well-being: The Issues Explored. Brisbane: Brisbane North Division of General Practice; 2000. 
32. Departments of General Practice, University of Melbourne and Monash University. GP Wellbeing Project - Final Report. 2001:Melbourne: Commonwealth Department of Health and Aged Care; 2001.

33. Frank E. Physician health and patient care. JAMA. 2004;291(5):637.

34. Frank E, Breyan J, Elon L. Physician disclosure of healthy personal behaviors improves credibility and ability to motivate. Arch Fam Med. 2000;9(3):287-290.

35. Bleich SN, Bennett WL, Gudzune KA, Cooper LA. Impact of physician BMI on obesity care and beliefs. Obesity. 2012;20(5):999-1005.

36. Rogers LQ, Gutin B, Humphries MC, et al. Evaluation of internal medicine residents as exercise role models and associations with self-reported counseling behavior, confidence, and perceived success. Teach Learn Med. 2006;18(3):215-221.

37. Kreuter MW, Chheda SG, Bull FC. How does physician advice influence patient behavior? Evidence for a priming effect. Arch Fam Med. 2000;9(5):426-433.

38. The WHO STEPwise approach to Surveillance of noncommunicable diseases (STEPS); 2018. Available from: http: //www.who.int/chp/ steps/en. Accessed July 31, 2018.

39. World Health Organization. Obesity: Preventing and Managing the Global Epidemic. Geneva: WHO Technical Report Series World Health Organization; 2000:8-9.

40. World Health Organization. Waist Circumference and Waist-Hip Ratio: Report of a WHO Expert Consultation. Geneva; 2008:8-11.

41. International Diabetes Federation criteria for ethnic or country-specific values for waist circumference IDF. The IDF Consensus Worldwide Definition of the Metabolic Syndrome. International Diabetes Federation (IDF); 2006. Available from: https://www.pitt.edu/ super1/ Metabolic/IDF1.pdf. Accessed June 21, 2018.

42. Okosun IS, Cooper RS, Rotimi CN, Osotimehin B, Forrester T. Association of waist circumference with risk of hypertension and type 2 diabetes in Nigerians, Jamaicans, and African-Americans. Diabetes Care. 1998;21(11):1836-1842.

43. Okosun IS, Liao Y, Rotimi CN, Choi S, Cooper RS. Predictive values of waist circumference for dyslipidemia, type 2 diabetes and hypertension in overweight White, Black, and Hispanic American adults. $J$ Clin Epidemiol. 2000a;53(4):401-408.

44. Okosun IS, Rotimi CN, Forrester TE, et al. Predictive value of abdominal obesity cut-off points for hypertension in Blacks from West African and Caribbean island nations. Int J Obes. 2000b;24(2):180-186.

45. Bacopoulou F, Efthymiou V, Landis G, Rentoumis A, Chrousos GP. Waist circumference, waist-to-hip ratio and waist-to-height ratio reference percentiles for abdominal obesity among Greek adolescents. BMC Pediatr. 2015;15(1):50.

46. Perloff D, Grim C, Flack J, et al. Human blood pressure determination by sphygmomanometry. Circulation. 1993;88(5):2460-2470.

47. JNC 7. National High Blood Pressure Education Program. The Seventh report of the Joint National Committee on Prevention, Detection, Evaluation and Treatment of High Blood Pressure. Hypertension 2003;42:1206-1252.

48. Ng M, Fleming T, Robinson M, et al. Global, regional, and national prevalence of overweight and obesity in children and adults during 1980-2013: a systematic analysis for the Global Burden of Disease Study 2013. Lancet. 2014;384(9945):766-781.

49. Kyle RG, Wills J, Mahoney C, Hoyle L, Kelly M, Atherton IM. Obesity prevalence among healthcare professionals in England: a cross-sectional study using the Health Survey for England. BMJOpen. 2017;7(12):e018498.

50. Ahmed HF, Qader SS, Hussene BM. Prevalence of metabolic syndrome among health care providers. Merit Res J Med Med Sci. 2014;2(10):238-244.

51. Iwuala SO, Ayankogbe OO, Olatona F, et al. Obesity among health service providers in Nigeria: danger to long term health worker retention? Pan Afr Med J. 2015;22:1.

52. Al Alwan I, Badri M, Al-Ghamdi M, Aljarbou A, Alotaibi H, Tamim H. Prevalence of self-reported cardiovascular risk factors among Saudi physicians: a comparative study. Int J Health Sci. 2013;7(1):3-13.
53. Beck M. Checking up on the doctor: what patients can learn from the way physicians take care of themselves. Wall Street J. 2010. Available from: http://online.wsj.com/articles/SB100014240527487041135045 75264364125574500. Accessed October 1, 2014.

54. Alarjan JF, Hindawi OS, Judge LW, Aleyadh ZA, Bellar DM. Prevalence of obesity and behaviors associated with the development of metabolic disease among medical practitioners in Jordan. $J E d u c$ Health Promot. 2015;4:17.

55. Beigh SH, Jain S. Prevalence of metabolic syndrome and gender differences. Bioinformation. 2012;8(13):613-616.

56. Akhter O, Fiazuddin F, Shaheryar A, et al. Central adiposity is significantly higher in female compared to male in Pakistani type 2 diabetes mellitus patients. Indian J Endocrinol Metab. 2015;19(1):72-76.

57. Merabet DH, Reguig KB. Prevalence of general and abdominal obesity on total population of Western Algeria (Province of Sidi Bel Abbes). Public Health Res. 2016;6(6):149-156.

58. Balkau B, Deanfield JE, Despres J-P, et al. International Day for the Evaluation of Abdominal Obesity (IDEA): a study of waist circumference, cardiovascular disease, and diabetes mellitus in 168000 primary care patients in 63 countries. Circulation. 2007;116(17): 1942-1951.

59. Lakka H, Lakka TA, Tuomilehto J, Salonen JT. Abdominal obesity is associated with increased risk of acute coronary events in men. Eur Heart J. 2002;23(9):706-713.

60. Snijder MB, van Dam RM, Visser M, Seidell JC. What aspects of body fat are particularly hazardous and how do we measure them? Int J Epidemiol. 2006;35(1):83-92.

61. Akinlua JT, Meakin R, Umar AM, Freemantle N. Current prevalence pattern of hypertension in Nigeria: a systematic review. PLoS One. 2015;10(10):e0140021.

62. Ulasi I, Ijoma CK, Onwubere BJC, Arodiwe E, Onodugo O, Okafor C. High prevalence and low awareness of hypertension in a market population in Enugu, Nigeria. Int J Hypertens. 2011; 2011:869675.

63. Ogah OS, Okpechi I, Chukwuonye Ii AJO. Blood pressure, prevalence of hypertension and hypertension related complications in Nigerian Africans: a review. World J Cardiol. 2012;4(12):327-340.

64. Calhoun DA, Jones D, Textor S, et al. Resistant hypertension: diagnosis, evaluation, and treatment: a scientific statement from the American Heart Association Professional Education Committee of the Council for High Blood Pressure Research. Circulation. 2008;117(25):e510-e526.

65. Etty Osher E, Stern N. Obesity in elderly subjects: in sheep's clothing perhaps, but still a wolf! Diabetes Care. 2009;32(Suppl 2):S398-S402.

66. Jouven X, Zureik M, Desnos M, Guerot C, Ducimetiere P. Resting heart rate as a predictive risk factor for sudden death in middle-aged men. Cardiovasc Res. 2001;50(2):373-378.

67. Jouven X, Empana JP, Escolano S, et al. Relation of heart rate at rest and long-term ( $>20$ years) death rate in initially healthy middle-aged men. Am J Cardiol. 2009;103(2):279-283.

68. Paillard F, Tardif JC. Potential benefits of pure heart rate reduction. Medicographia. 2008;3:222-223.

69. Goran Davidovic G, Iric-Cupic V, Milanov S, Dimitijevic A, PetrovicJanicijevic M. When heart goes "BOOM" to fast. Heart rate greater than 80 as mortality predictor in acute myocardial infarction. $\mathrm{Am} J$ Cardiovasc Dis. 2013;3(3):120-128.

70. van de Vidjer S, Akinyi H, Oti S, et al. Status report on hypertension in Africa - consultative review for the sixth session of the African union conference of Ministers of health on NCDS. Pan Afr Med J. 2013; $16: 38$.

71. Cappuccio FP, Miller MA. Cardiovascular disease and hypertension in sub-Saharan Africa: burden, risk and interventions. Intern Emerg Med. 2016;11(3):299-305.

72. Kay MP, Mitchell Gk DMCB. Doctors do not adequately look after their own physical health. MJA. 2004;181:368-370.

73. Samkoff JS, Hockenberry S, Simon LJ, Jones RL. Mortality of young physicians in the United States, 1980-1988. Acad Med. 1995;70(3):242-244. 
74. Davidson S, Schattner P. Doctors' health-seeking behaviour: a questionnaire survey. Med J Aust. 2003;179:302-305.

75. Nyman K. The health of general practitioners. A pilot survey. Aust FAM Physician. 1991;20:637-641; 644-645.

76. Wines AP, Khadra MH, Wines RD. Surgeon, don't heal thyself: a study of the health of Australasian urologists. ANZJ Surg. 1998;68(11):778-781.

77. Wachtel TJ, Wilcox VL, Moulton AW, Tammaro D, Stein MD. Physicians' utilization of health care. J Gen Intern Med. 1995;10(5):261-265.

78. Cushman WC, Ford CE, Cutler JA, et al. Success and predictors of blood pressure control in diverse North American settings: The Antihypertensive and Lipid-Lowering Treatment to Prevent Heart Attack Trial (ALLHAT). J Clin Hypertens. 2002;4:393-404.

79. Hansson L, Zanchetti A, Carruthers SG, et al. Effects of intensive blood-pressure lowering and low-dose aspirin in patients with hypertension: principal results of the Hypertension Optimal Treatment (HOT) randomised trial. Lancet. 1998;351(9118):1755-1762.

80. Materson BJ, Reda DJ, Cushman WC, et al. Single-drug therapy for hypertension in men. A comparison of six antihypertensive agents with placebo. The Department of Veterans Affairs Cooperative Study Group on Antihypertensive Agents. N Engl J Med. 1993;328:914-921.

81. Etuk E, Isezuo SA, Chika A, Akuche J, Ali M. Prescription pattern of anti-hypertensive drugs in a tertiary health institution in Nigeria. Ann Afr Med. 2008;7(3):128-132.

82. Rimoy GH, Justin-Temu M, Nilay C. Prescribing patterns and cost of antihypertensive drugs in private hospitals in Dar es Salaam, Tanzania. East Central Afr J Pharm Sci. 2008;11:69-73.

83. Bakare OQ, Akinyinka MR, Goodman O, et al. Antihypertensive use, prescription patterns, and cost of medications in a Teaching Hospital in Lagos, Nigeria. Niger J Clin Pract. 2016;19(5):668-672.

84. van der Sande MAB, Walraven GEL, Milligan PJM, et al. Family history: an opportunity for early interventions and improved control of hypertension, obesity and diabetes. Bull World Health Org. 2001;79:321-328.

85. Mitsumata K, Saitoh S, Ohnishi H, Akasaka H, Miura T. Effects of parental hypertension on longitudinal trends in blood pressure and plasma metabolic profile: mixed-effects model analysis. Hypertension. 2012;60(5):1124-1130.

86. Ranasinghe P, Cooray DN, Jayawardena R, Katulanda P. The influence of family history of hypertension on disease prevalence and associated metabolic risk factors among Sri Lankan adults. BMC Public Health. 2015;15(1):576.

87. Stamler R, Stamler J, Riedlinger WF, Algera G, Roberts RRH. Family (parental) history and prevalence of hypertension. Results of a nationwide screening program. JAMA. 1979;241(1):43-46.

88. Masoud Amini M, Janghorbani M. Diabetes and impaired glucose regulation in first-degree relatives of patients with type 2 diabetes in Isfahan, Iran: prevalence and risk factors. Rev Diabet Stud. 2007; 4(3):169-176.

89. Owen K, Ayres S, Corbett S, Hattersley A. Increased risk of diabetes in first-degree relatives of young-onset type 2 diabetic patients compared with relatives of those diagnosed later. Diabetes Care. 2002;25(3):636-637.

90. Nigeria-Smoking prevalence, males ( $\%$ of adults). Available from: https://tradingeconomics.com. Accessed June 21, 2018.

91. WHO report on the global tobacco epidemic, 2017? Country profile. Nigeria.

92. Nanchahal K, Ashton WD, Wood DA. Alcohol consumption, metabolic cardiovascular risk factors and hypertension in women. Int J Epidemiol. 2000;29:57-64.

93. Working Group of the Royal Colleges of General Practitioners, Physicians and Psychiatrists. Alcohol, Cardiovascular Disease, Sensible Limits and Population Health. London: Royal College of Physicians; 1995.

94. Thun MJ, Peto R, Lopez AD, et al. Alcohol consumption and mortality among middle-aged and elderly U.S. adults. $N$ Engl J Med. 1997;337(24):1705-1714.
95. Yusuf S, Hawken S, Ônpuu S, et al. Effect of potentially modifiable risk factors associated with myocardial infarction in 52 countries (the INTERHEART study): case-control study. Lancet. 2004;364(9438):937-952.

96. Haskell WL, Lee IM, Pate RR, et al. Physical activity and public health: updated recommendation for adults from the American College of Sports Medicine and the American Heart Association. Circulation. 2007;116(9):1081-1093.

97. Barengo N, Hu G, Lakka T, Pekkarinen H, Nissinen A, Tuomilehto J. Low physical activity as a predictor for total and cardiovascular disease mortality in middle-aged men and women in Finland. Eur Heart J. 2004;25(24):2204-2211.

98. Yu S, Yarnell JW, Sweetnam PM, Murray L. What level of physical activity protects against premature cardiovascular death? The Caerphilly study. Heart. 2003;89(5):502-506.

99. Oguma Y, Shinoda-Tagawa T. Physical activity decreases cardiovascular disease risk in women: review and meta-analysis. Am J Prev Med. 2004;26(5):407-418.

100. Bazargan M, Makar M, Bazargan-Hejazi S, Wolf KE. Preventive lifestyle, and personal health behaviors among physicians. Acad Psychiatry. 2009; 33(4)289-95.

101. Barnett KG. Physician obesity: the tipping point. Global Adv Health Med. 2014;3(6):8-10.

102. Cappuccio FP, Macgregor GA. Does potassium supplementation lower blood pressure? A meta-analysis of published trials. J Hypertens. 1991;9(5):465-473.

103. Whelton PK, He J, Cutler JA, et al. Effects of oral potassium on blood pressure: meta-analysis of randomized controlled clinical trials. JAMA. 1997;277:1624-1632.

104. Geleijnse JM, Kok FJ, Grobbee DE. Blood pressure response to changes in sodium and potassium intake: a -meta regression analysis of randomised trials. J Hum Hypertens. 2003;17(7):471-480.

105. Brancati FL, Appel LJ, Seidler AJ, Whelton PK. Effect of potassium supplementation on blood pressure in African Americans on a low potassium diet: a randomized, double-blind, placebo-controlled trial. Arch Intern Med. 1996;156:61-67.

106. Appel LJ, Moore TJ, Obarzanek E, et al. A clinical trial of the effects of dietary patterns on blood pressure: DASH Collaborative Research Group. N Engl J Med. 1997;336:1117-1124.

107. Naismith DJ, Braschi A. The effect of low-dose potassium supplementation on blood pressure in apparently healthy volunteers. Br J Nutr. 2003;90(01):53-60.

108. Appel LJ, Brands MW, Daniels SR, Karanja N, Elmer PJ, Sacks M. Dietary approaches to prevent and treat hypertension: a scientific statement from the American Heart Association. Hypertension. 2006;47:296-308.

109. U.S. Department of Health and Human Services. National Institutes of Health. National Heart, Lung, and Blood Institute. Your Guide To Lowering Your Blood Pressure With DASH: DASH eating plan. NIH Publication No. 06-4082. 2006: Originally Printed 1998 Revised April 2006.

110. Snowdon DA, Phillips RL, Fraser GE. Meat consumption and fatal ischemic heart disease. Prev Med. 1984;13(5):490-500.

111. $\mathrm{Fb} \mathrm{H}$, Stampfer MJ, Manson JE, et al. Dietary saturated fats and their food sources in relation to the risk of coronary heart disease in women. Am J Clin Nutr. 1999;70(6):1001-1008.

112. Erlinger T, Appel L. The relationship between meat intake and cardiovascular disease. Baltimore, MD: Johns Hopkins Center for a Livable Future; 2003.

113. Krauss RM, Eckel RH, Howard B, et al. AHA Dietary Guidelines: Revision 2000: A statement for healthcare professionals from the Nutrition Committee of the American Heart Association. Circulation. 2000;102(18):2284-2299.

114. Ornish D, Brown SE, Scherwitz LW, et al. Can lifestyle changes reverse coronary heart disease? Lancet. 1990;336(8708):129-133.

115. Tang WH, Wang Z, Levison BS, et al. Intestinal microbial metabolism of phosphatidylcholine and cardiovascular risk. N Engl J Med. 2013;368(17):1575-1584. 
116. Zhu W, Wang Z, Tang WHW, Hazen SL. Gut microbe-generated trimethylamine $N$-oxide from dietary choline is prothrombotic in subjects. Circulation. 2017;135(17):1671-1673.

117. Institute of Medicine. Dietary Reference Intakes for Water, Potassium, Sodium, Chloride, and Sulfate. Washington, DC: The National Academies Press; 2005.

118. Marshall TA, Eichenberger Gilmore JM, Broffitt B, Stumbo PJ, Levy $\mathrm{SM}$. Diet quality in young children is influenced by beverage consumption. J Am Coll Nutr. 2005;24(1):65-75.

119. Frary CD, Johnson RK, Wang MQ. Children and adolescents' choices of foods and beverages high in added sugars are associated with intakes of key nutrients and food groups. JAdolesc Health. 2004;34(1):56-63.

120. Sohn W, Burt BA, Sowers MR. Carbonated soft drinks and dental caries in the primary dentition. J Dent Res. 2006;85(3):262-266.

121. Malik VS, Popkin BM, Bray GA, et al. Sugar-sweetened beverages and risk of metabolic syndrome and type 2 diabetes: a meta-analysis. Diabetes Care. 2010;33(11):2477-2483.

122. Lien L, Lien N, Heyerdahl S, Thoresen M, Bjertness E. Consumption of soft drinks and hyperactivity, mental distress, and conduct problems among adolescents in Oslo, Norway. Am J Public Health. 2006;96(10):1815-1820.

123. Shi Z, Taylor AW, Wittert G, Goldney R, Gill TK. Soft drink consumption and mental health problems among adults in Australia. Public Health Nutr. 2010;13(7):1073-1079.

124. Park S, Sherry B, Foti K, Blanck HM. Self-reported academic grades and other correlates of sugar-sweetened soda intake among US adolescents. J Acad Nutr Diet. 2012;112(1):125-131.

125. Nettleton JA, Lutsey PL, Wang Y, et al. Diet soda intake and risk of incident metabolic syndrome and type 2 diabetes in the Multi-Ethnic Study of Atherosclerosis (MESA. Diabetes Care. 2009;32(4):688-694.
126. Gardener H, Rundek T, Markert M, Wright CB, Elkind MS, Sacco RL. Diet soft drink consumption is associated with an increased risk of vascular events in the Northern Manhattan Study. J Gen Intern Med. 2012;27(9):1120-1126.

127. Popkin BM, Nielsen SJ. The sweetening of the world's diet. Obes Res. 2003;11(11):1325-1332.

128. Bains A, Rashid MA. Junk food and heart disease: the missing tooth. $J$ R Soc Med. 2013;106(12):472-473.

129. Azadbakht L, Esmaillzadeh A. Fast foods and risk of chronic diseases. $J$ Res Med Sci. 2008;13(1):1-2.

130. Anand SS, Hawkes C, de Souza RJ, et al. Food consumption and its impact on cardiovascular disease: importance of solutions focused on the globalized food system: a report from the workshop convened by the World Heart Federation. J Am Coll Cardiol. 2015;66(14):1590-1614.

131. Radzeviciene L, Ostrauskas R. Adding salt to meals as a risk factor of type 2 diabetes mellitus: a case-control study. Nutrients. 2017;9(1):67.

132. Millen BE, Abrams S, Adams-Campbell L, et al. The 2015 Dietary Guidelines Advisory Committee scientific report: development and major conclusions. Adv Nutr. 2016;7(3):438-444.

133. Mugavero KL, Gunn JP, Dunet DO, Bowman BA. Sodium reduction: an important public health strategy for heart health. J Public Health Manag Pract. 2014;20(1 Suppl 1):S1-S5.

134. Sacks FM, Svetkey LP, Vollmer WM, et al. Effects on blood pressure of reduced dietary sodium and the dietary approaches to stop hypertension (DASH) diet. $N$ Engl J Med Overseas Ed. 2001;344(1):3-10.

135. National Research Council. Nutrition Education in US Medical schools. Washington, DC: The National Academies Press; 1985.
Vascular Health and Risk Management

\section{Publish your work in this journal}

Vascular Health and Risk Management is an international, peerreviewed journal of therapeutics and risk management, focusing on concise rapid reporting of clinical studies on the processes involved in the maintenance of vascular health; the monitoring, prevention and treatment of vascular disease and its sequelae; and the involvement of

\section{Dovepress}

metabolic disorders, particularly diabetes. This journal is indexed on PubMed Central and MedLine. The manuscript management system is completely online and includes a very quick and fair peer-review system, which is all easy to use. Visit http://www.dovepress.com/ testimonials.php to read real quotes from published authors. 